\title{
Identifikasi Kesiapsiagaan Guru PAUD sebagai Upaya Pengurangan Risiko Bencana Banjir di Bandung
}

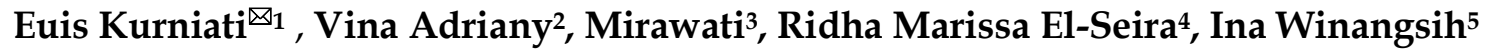 \\ Pendidikan Anak Usia Dini, Universitas Pendidikan Indonesia \\ DOI: $10.31004 /$ obsesi.v4i2.388
}

\begin{abstract}
Abstrak
Artikel ini bertujuan untuk menggambarkan bagaimana kesiapsiagaan guru PAUD yang tinggal di kawasan rawan bencana banjir, sebagai upaya pengurangan risiko bencana banjir. Kota Bandung memiliki curah hujan yang tinggi, sehingga Bandung menjadi salah satu daerah yang rawan terhadap bencana banjir. Penelitian sebelumnya menunjukkan banyaknya kerugian yang disebabkan oleh bencana banjir. Penelitian ini menggunakan studi kasus, dengan melakukan wawancara dan forum group discussion, untuk mendalami pandangan guru PAUD dan kesiapsiagaannya terhadap bencana banjir. Temuan dalam penelitian ini menunjukkan bahwa guru PAUD sudah memiliki kesadaran akan potensi bencana banjir di wilayahnya, begitu juga faktor-faktor yang dapat menyebabkan banjir. Guru PAUD sudah mengetahui respon dan hal-hal yang perlu disiapkan dalam menghadapi bencana. Adapun upaya mitigasi yang dimasukkan dalam program sekolah baru terbatas pada pengenalan bencana banjir dalam pembelajaran bagi anak usia dini.
\end{abstract}

Kata Kunci: kesiapsiagaan; guru; paud; banjir.

\begin{abstract}
This article aims to illustrate how the attitude of preparedness of teachers living in areas prone to flood hazard as disaster risk reduction efforts. Flooding is one of the most frequent potential disasters in Bandung with high rainfall. Previous research showed many losses caused by flood disaster. The study used case studies, with observations, interviews, and group discussion forums to deepen the PAUD teacher's view of flood relief and PAUD teacher preparedness for flood disasters. Findings in this study show that PAUD teachers already have awareness of the potential flood disaster in the region, as well as various factors that can cause flooding. The preparedness of a disaster-related teacher is conducted through the provision of information on parents of students related to the potential flood of the efforts that parents can do when flooding occurs. The mitigation efforts included in the new school program are limited to the introduction of flood disaster in learning for early childhood.
\end{abstract}

Keywords: preparedness; teacher; paud; flood

Copyright (c) 2020 Euis Kurniati, Vina Adriany, Mirawati, Ridha Marissa El-Seira, Ina Winangsih

$\triangle$ Corresponding author:

Email Address : euiskurniati@upi.edu

Received 15 December 2019, Accepted 10 February 2020, Published 16 Febaruary 2020 


\section{PENDAHULUAN}

Indonesia merupakan negara kepulauan yang dilalui jalur ring of fire atau cincin api pasifik. Selain memiliki sumber daya alam yang melimpah, disisi lain juga Indonesia memiliki potensi bencana alam yang tinggi. Seperti yang disebutkan oleh Centre of Research on the Epidemiology of Disaster, 2018 (dalam Proulx \& Aboud, 2019) bahwa secara konsisten, Indonesia menempati peringkat lima besar dalam urutan negara yang sering mengalami bencana alam. Negara Indonesia merupakan salah satu di wilayah ASEAN yang berada diantara Samudra Hindia dan Samudra Pasifik yang terletak diantara beberapa lempeng tektonik (UNISDR, 2010). Hal tersebut yang menyebabkan hampir seluruh potensi bencana alam seperti gempa bumi, letusan gunung berapi, tsunami dan bencana alam lainnya berpotensi di Indonesia. Setiap wilayah di Indonesia memiliki berbagai potensi kebencanaan yang beragam berdasarkan letak dan bentuk geologis wilayah masing-masing (Amri, Bird, Ronan, Haynes, \& Towers, 2017).

Berdasarkan data kejadian bencana yang dilaporkan oleh Badan Nasional Penanggulangan Bencana (BNPB, 2016), bencana banjir di Kota Bandung menjadi bencana yang lebih sering terjadi dibandingkan bencana lainnya. Kondisi alam dan sejarah kebencanaan di Indonesia, membuat masyarakat Indonesia harus siaga. Secara khusus dalam pendidikan, kesadaran guru terhadap bencana haruslah menjadi sebuah kompetensi standar (Amri et al., 2017). Dalam hal perilaku atau kesadaran masyarakat terhadap lingkungan, masih banyak masyarakat yang kurang menyadari bahwa perilaku sehari-hari atau kegiatan yang dilakukannya dapat merugikan orang lain, baik di daerah tersebut maupun di daerah lain.

Potensi kebencanaan yang sering terjadi di Indonesia ialah banjir. Dari total 703 bencana yang terjadi sepanjang tahun 2012, ada 193 banjir yang terjadi di Indonesia (Prihanggo, Darmawan, \& Wikantika, 2014). Salah satu wilayah di Indonesia yang sering terkena bencana banjir yaitu wilayah Bandung (Rosyidie, 2013a). Wilayah Bandung memiliki bentuk geologis seperti cekungan akan memudahkan air hujan berkumpul dan menggenang sehingga menjadi rawan banjir (Kurniasih \& Sukaesih, 2017). Tidak hanya bentuk geologis dari wilayah Bandung, tetapi terdapat berbagai faktor lain yang menyebabkan risiko banjir di wilayah Bandung.

Topografi wilayah Bandung, perubahan iklim, dan perkembangan sosial ekonomi di wilayah Bandung juga menjadi penyebab lain terjadinya banjir di Bandung . Faktor-faktor penyebab terjadinya banjir akan saling berhubungan satu sama lain. Ketika topografi wilayah bandung yang berpotensi menyebabkan banjir dengan iklim yang memiliki curah hujan yang tinggi dan perilaku masyarakat belum menyadari tentang banjir maka akan memperkuat potensi terjadinya banjir di wilayah Bandung.

Pada tahun 2018 dirangkum dari DetikNews.com kejadian banjir beberapa kali melanda Bandung, beberapa diantaranya yaitu banjir di sejumlah titik di daerah Bandung bagian timur, jebolnya tanggul Sungai Cironggeng, banjir bandang akibat tanggul Sungai Cipamokolan jebol berdampak pada banjir di Cicaheum. Meluapnya Sungai Cicabe dan Cileuweung akibat hujan dari Bandung bagian utara. Terjadinya banjir bandang yang membuat jalur jalan AH Nasution lumpuh total akibat lumpur, menyebabkan minibus Xenia terseret sejauh $10 \mathrm{KM}$, belasan mobil yang berada di bengkel Jalan $\mathrm{AH}$ Nasution terseret hingga saling bertumpuk. Total terdapat 17 mobil dan 12 motor yang menjadi korban. Adapun banjir di Jalan Pagarsih yang menyebabkan dua mobil hampir hanyut diterjang arus Sungai Citepus yang meluap meski sudah ada tol air. Semenjak ada tol air banjir meluas ke pemukiman warga di Kelurahan Cibadak Kecamatan Astanaanyar hingga rumah dan mushala warga tergerus air hingga roboh, di penghujung tahun 2018 banjir masih kembali terjadi di kawasan Pagarsih (Ispranoto, 2018). Berikut adalah salah satu contoh dokumentasi bencana banjir di Kota Bandung: 


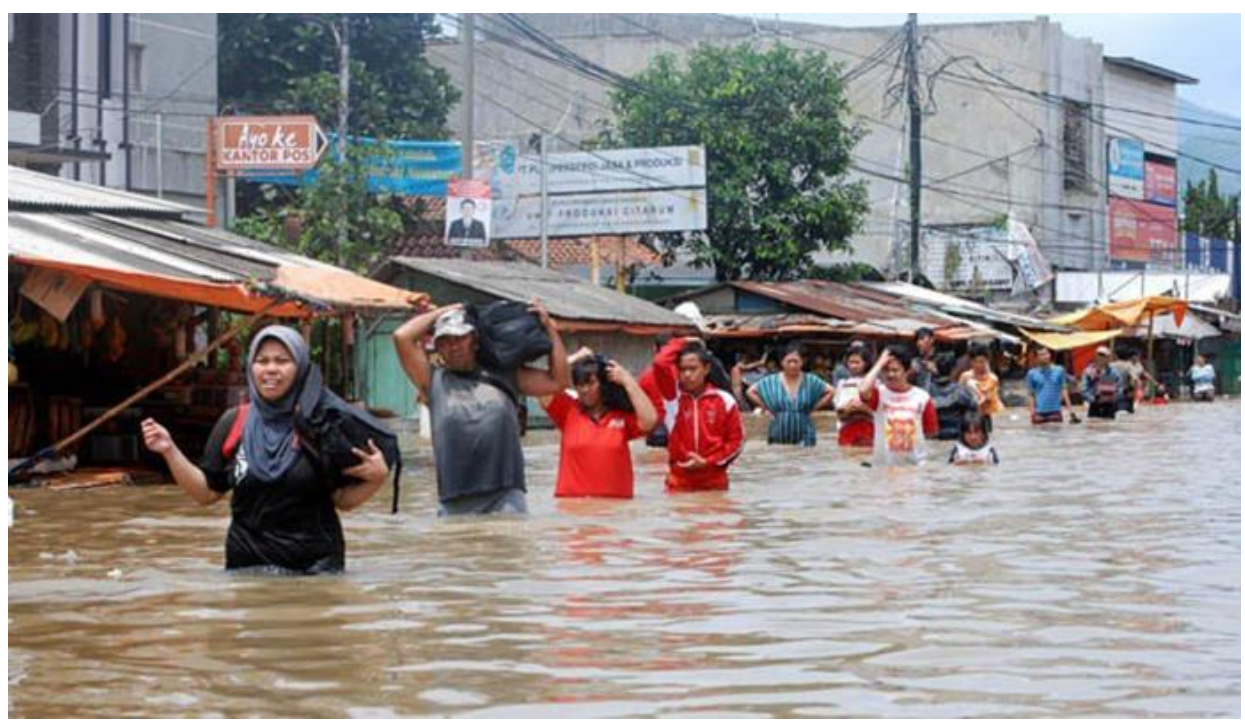

\section{Gambar 1. Kejadian Bencana Banjir di Baleendah, Kota Bandung} (www. indowarta.com)

Banjir juga dapat memiliki dampak yang sangat fatal pada keselamatan seseorang. Pada daerah Dayeuh Kolot terdapat seorang anak laki-laku berusia 13 tahun meninggal karena tersengat listrik saat terjadi bencana banjir. Seorang pria usia 40 tahun meninggal terseret arus banjir pada Maret 2016 dua orang terperangkap di dalam rumah dan terendam banjir (Kantor SAR Bandung 2016), tiga orang hilang karena mengungsi sendiri ke gedung yang berada di tepi sungai Citarik (online Berita News 2016) dan berbagai macam kasus lain yang sudah banyak ditemukan. Hal-hal yang tidak diharapkan ini dapat dihindari dengan adanya kewaspadaan pada lingkungan sekitar (Irzalinda \& Sofia, 2019; Kurniasih, 2016).

Ispranoto (2018) dari DetikNews.com memaparkan bahwa berbagai upaya telah dilakukan Pemerintah. Berbagai upaya yang dimaksudkan diantaranya, pembuatan Tol Air, membangun ulang tanggul yang bocor, program mengurangi sampah besar di sungai, Operasi Tangkap Tangan (OTT), hingga meresmikan pembangunan Kolam Retensi Sirnaraga sebagai penampungan dari Sungai Citepus.

Oded M Danial yang menggantikan Ridwan Kamil sebagai Wali Kota Bandung menurut Ispranoto (2018) dalam DetikNews.com kemudian melakukan berbagai upaya untuk mencegah banjir kembali terjadi. Salah satunya adalah pengerukan sungai, mengerahkan pasukan untuk membersihkan gorong-gorong, hingga menggaungkan program Kurangi Pisahkan Manfaatkan (Kang Pisman) untuk menyelesaikan masalah sampah. Kang Pisman juga menjadi program utama dalam 100 hari kerja Oded. Khusus untuk banjir Pagarsih dan sekitarnya, Oded berencana memindahkan warga bantaran sungai ke rumah susun. Sementara itu Ridwan Kamil sebagai Gubernur Jabar berencana membuat Unit Kerja Cekungan Bandung yang menggawangi masalah Bandung Raya.

Upaya pencegahan dan penanggulangan banjir sudah dilakukan perlu perhatian dari masyarakat sekitar, dari sebelum bencana banjir datang, saat bencana banjir terjadi, hingga setelah bencana banjir terjadi (Purwani, Fridani, \& Fahrurrozi, 2019). Terutama mengenai sampah yang menghambat jalur air sehingga menutupi aliran air dan mengakibatkan banjir. Kekhawatiran tentang pengelolaan sampah harus dipublikasikan, mengingat bahwa banjir yang terjadi di Bandung bukan hanya dari topografi dan curah hujan saja melainkan perilaku masyarakat dalam memahami potensi bencana banjir yang masih kurang (Kurniasih \& Sukaesih, 2017). Hal ini perlu dilihat lebih jauh pada perilaku masyarakat dalam kehidupan sehari-hari sejak dini. Pembiasaan berperilaku sejak dini untuk memahami potensi banjir di wilayah Bandung ini perlu di sampaikan sedini mungkin pada anak melalui proses pendidikan yang dilakukan di lingkungan sekolah oleh guru pada jenjang anak usia dini. 
Pengurangan risiko bencana sangat penting dijadikan prioritas dalam pendidikan karena program pendidikan pengurangan risiko bencana di sekolah dapat menjadi cara yang menjanjikan untuk menanamkan kesiapsiagaan pada anak tentang mitigasi dan respon bencana (Amri dkk., 2017; Proulx \& Aboud, 2019). Seperti contoh, saat terjadi fenomena alam yang berkaitan dengan cuaca dan geofisika, anak dapat mengatasi ketakutannya (Mutch, 2014, 2015).

Sekolah dapat melibatkan anak dalam pendidikan pengurangan risiko bencana secara structural maupun non-struktural yang melingkupi tahap identifikasi, aplikasi, dan evaluasi (Pfefferbaum, Pfefferbaum, \& Van Horn, 2018; Rosyidie, 2013a) Kualitas pendidikan pengurangan risiko bencana juga dientukan oleh keinginan dan kreatifitas guru. Cara sistematis dalam meningkatkan kemampuan guru dalam hal ini adalah dengan mengintegrasikan pendidikan pengurangan risiko bencana pada program pendidikan guru. Bahkan apabila orang dewasa di sekolah sudah terlatih dan menanamkan pendidikan pengurangan risiko bencana, anak usia dini berpotensi untuk memberikan kontribusi dalam kegiatan pengurangan risiko bencana dan bisa berperan sebagai agen aktif dalam mengidentifikasi risiko di sekolah dan lingkungan sekitar dan menyebarkan informasi tentang risiko bencana pada teman dan keluarganya (Mutch, 2014, 2015; Proulx \& Aboud, 2019).

\section{METODOLOGI}

Penelitian ini menggunakan desain studi kasus. Menurut Yin (2014), studi kasus memaparkan fenomena fakta secara lebih menyeluruh dan mendalam. Desain ini digunakan untuk mengetahui bagaimana kesadaran guru PAUD tentang bencana dan bagaimana kesiapsiagaan guru PAUD terhadap bencana berdasarkan perilaku sehari-hari.

Penelitian melibatkan guru yang berada di Kota Bandung, khusunya yang sering mengalami bencana alam banjir. Penelitian dilakukan melalui wawancara dan focus group discuccion (FGD). Data dalam penelitian ini dianalisis dengan menggunakan teknik grounded theory dan dilaporkan secara naratif. Adapun rancangan dalam penelitian ini meliputi tahapan yang digambarkan pada bagan sebagai berikut:

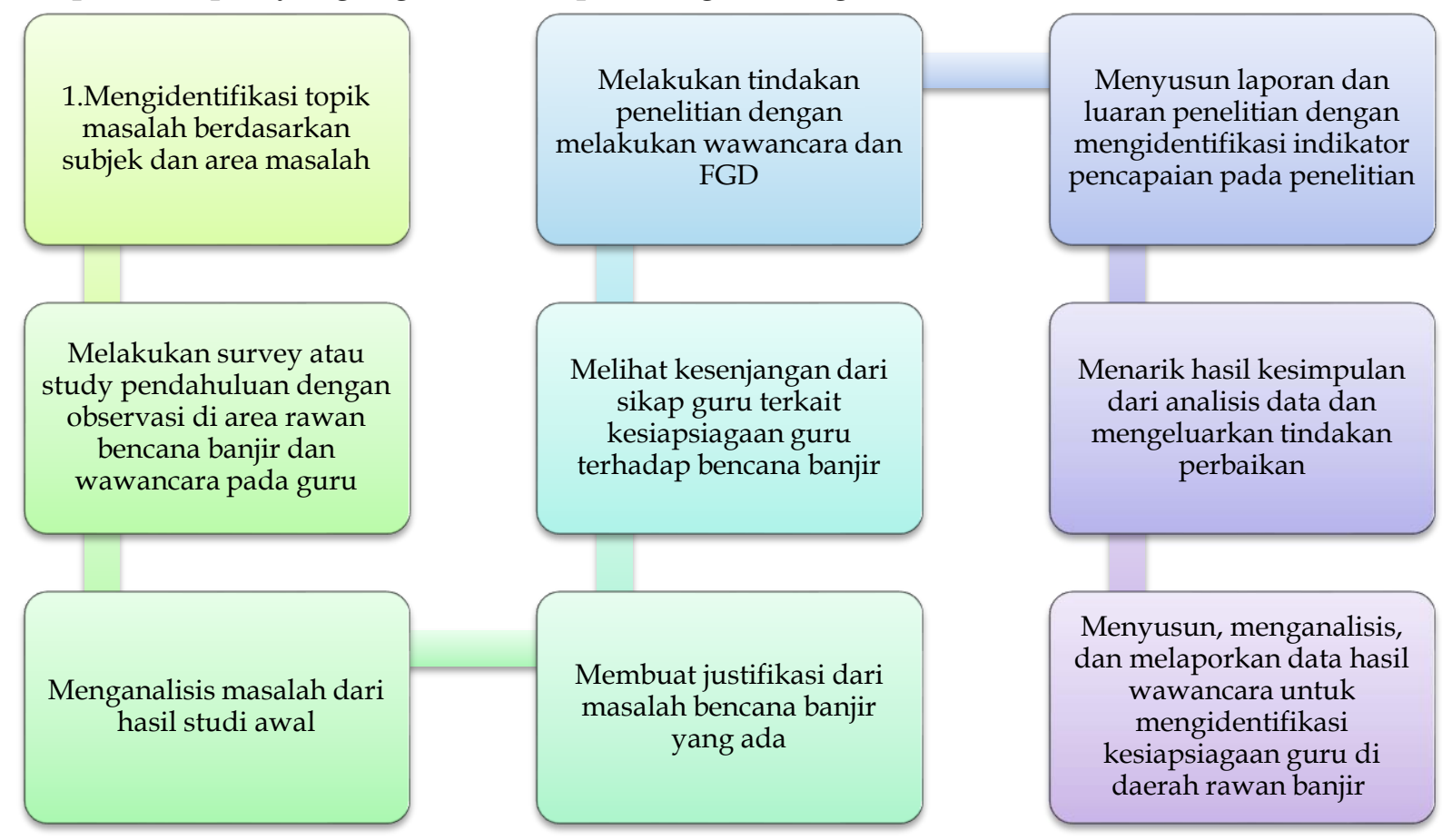

Gambar 2. Tahapan Penelitian 


\section{HASIL DAN PEMBAHASAN}

Penelitian ini melibatkan 5 guru sebagai partisipan, yang berada di Bandung, khusunya yang pernah mengalami bencana alam banjir. Penelitian dilakukan melalui wawancara dan focus group discuccion (FGD). Wawancara dilaksanakan pada hari Kamis, 8 Agustus 2019 di ruang kelas Gedung Pascasarjana Universitas Pendidikan Indonesia. FGD dilaksanakan pada Jumat, 13 September 2019 di ruang Kelas Gedung Fakultas Ilmu Pendidikan Universitas Pendidikan Indonesia. Proses wawancara yang dilakukan dapat dilihat pada gambar sebagai berikut:

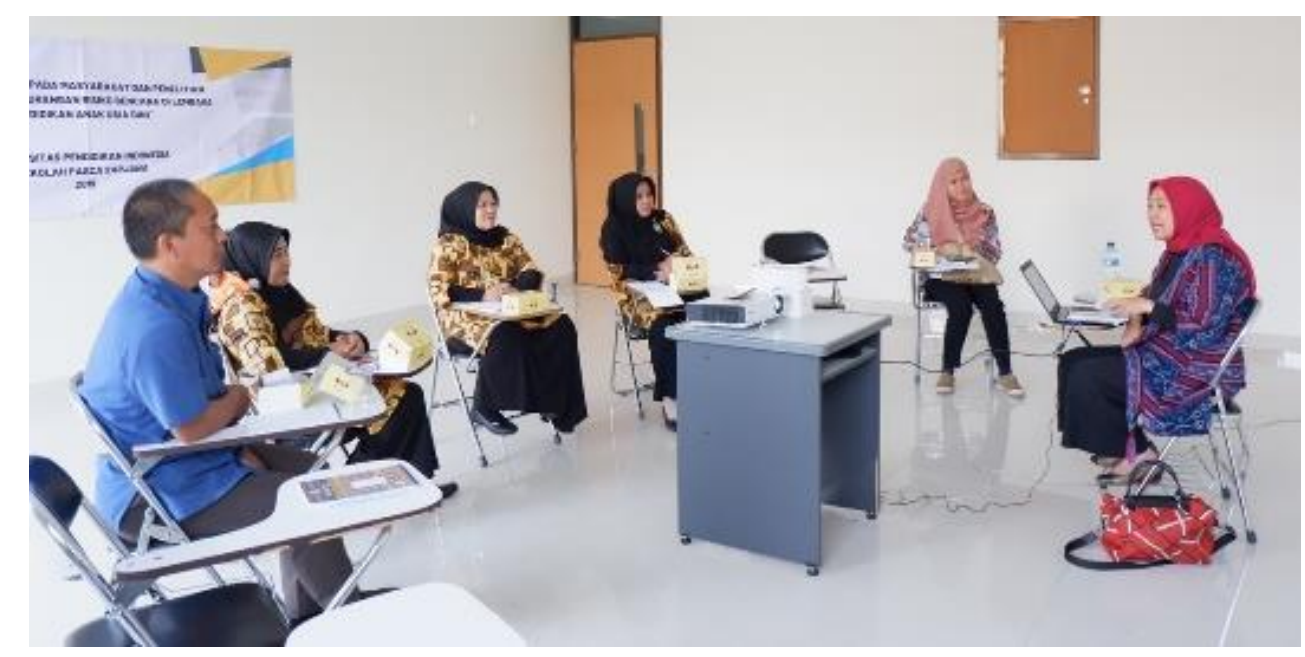

Gambar 3. Pelaksanaan Wawancara dengan Partisipan Penelitian

Adapun hasil penelitian berdasarkan wawancara dan focus group discussion di atas antara lain sebagai berikut:

\section{Kesadaran Guru tentang Potensi Bencana Banjir}

Berdasarkan data temuan dari hasil wawancara dan FGD, diketahui bahwa potensi bencana banjir diantaranya adalah kondisi topografi wilayah, curah hujan, dan sikap masyarakat setempat. Potensi tersebut dapat dikatakan potensi karena dapat disebabkan oleh manusia atau dampak fisik yang dapat menyebabkan hilangnya nyawa, cedera, atau dampak kesehatan lainnya, serta kerusakan dan kerugian pada properti, infrastruktur, mata pencaharian, penyediaan layanan, ekosistem dan sumber daya lingkungan (Coppola, 2011; Van Ackere, 2019). Kondisi-kondisi tersebut merupakan kondisi yang berdampak pada perubahan tata ruang atau guna lahan di suatu daerah yang kemudian menyebabkan terjadinya banjir (Rosyidie, 2013b).

"L" sebagai guru TK memahami bencana banjir yang merugikan yang terjadi di lingkungannya merupakan akibat dari kali yang kurang terjaga kebersihannya, maraknya sampah yang dibuang sembarangan dan sungai yang semakin dangkal sehingga air mudah meluap ketika curah hujan tinggi. L mengatakan "....itu pada saat hujan datang, sampah menumpuk, sementara kalinya tidak dalam, dangkal, ya sudah langsung (banjir terjadi)". Pernyataan dari L menunjukkan bahwa dia menyadari dan memahami potensi bencana banjir diakibatkan oleh perubahan guna lahan, pembuangan sampah, erosi dan sedimentasi, kawasan kumuh di sepanjang sungai, sistem pengendalian banjir yang tidak tepat, curah hujan tinggi, fisiografi sungai, kapasitas sungai yang tidak memadai, pengaruh air pasang, penurunan tanah, bangunan air, serta adanya kerusakan bangunan pengendali banjir (Kodoatie \& Syarief, 2002; Kusuma, Kuntoro, \& Silasari, 2011).

Sementara itu, P yang juga sebagai guru TK mengatakan “...di saya dulu kan mulai banjir tahun 2005, dulu itu belum pernah banjir kan, karena dataran saya agak tinggi juga, kan banyak lahan pohon-pohon ya, kolam-kolam, sawah-sawah, karena dari industry jadi di 
bangun dari serapan-serapan air itu". Pernyataan tersebut menggambarkan bahwa partisipan sudah mampu mengidentifikasi apa yang menjadi potensi bencana banjir di lingkungannya. Pengetahuan akan faktor-faktor penyebab banjir yang dimiliki oleh partisipan menunjukkan kesadarannya terkait potensi bencana banjir yang bisa terjadi di lingkungan tempat tinggalnya.

Pengetahuan akan faktor-faktor penyebab terjadinya bencana banjir merupakan salah satu poin penting dari kesadaran akan potensi bencana banjir yang penting untuk dimiliki oleh semua pihak. Dengan adanya kesadaran akan potensi bencana banjir, diharapkan dapat meningkatkan kemampuan masyarakat itu sendiri untuk membuat peta rawan bencana di daerahnya masing-masing dan mampu melaksanakan kesiapsiagaan serta pengurangan risiko atau dampak bencana secara mandiri (Hadi, 2007).

Identifikasi keberadaan potensi bencana bukan hanya dilihat dari faktor penyebab bencana, tetapi juga dilihat oleh partisipan intensitas curah hujan sebagai ancaman bencana banjir bagi partisipan. Curah hujan yang dimaksud bukanhanya curah hujan yang ada di daerah tersebut, namun juga curah hujan dari daerah yang letak geografisnya lebih tinggi dari pada daerah tempat parisipan tersebut. "...karena kan daerah ini, daerah cekung kan? Naah kayak perahu gitu kan?” ucap L. “...jadi kalau bandung hujan, udah aja kena” tambah K. Partisipan menunjukkan bahwa mereka memiliki kesadaran akan potensi bencana banjir. Identifikasi potensi bencana banjir tidak hanya dari daerah tempat partisipan tetapi juga dari daerah terdekat yang lebih tinggi secara geografis.

\section{Sikap Kesiapsiagaan Guru dalam Mengantisipasi dan Menanggulangi Risiko Bencana Banjir}

Bencana banjir yang terjadi di lingkungan partisipan biasanya menutup akses jalan utama, sehingga ketika terjadi banjir kegiatan belajar mengajar diliburkan dengan terpaksa. Pemberitahuan libur dilakukan melalui pesan whatsapp kepada orang tua murid. Hal tersebut diutarakan oleh "L" (Guru TK):

“...otomatiskan kalau di saya banjir, anak-anak juga stop sekolah karena jalan-jalannya ketutup. Warga belajarnya juga udah kebanjiran, jalan menuju ke sekolah juga udah kebanjiran. Bahkan kalo ada murid saya yang daerah Cikoneng, Bojongsoang mereka engga bisa lewat karena tempat yang dilewatinya sawahnya sepinggang."

Bencana banjir yang berulang membuat partisipan menyadari pola dari bencana banjir tersebut, "...jadi kita udah tau sekarang lagi musim tidak banjir, kursi bisa dipasang. Kan banjir juga ada berfase-fase kan tadi, nanti tinggian naik kursi. Tapi saya di atas saja, kehidupan saya di atas". Tindakan preventif partisipan sebagai seorang guru dalam mengantisipasi dan menanggulangi bencana banjir di TK ialah dengan menyimpan peralatan dan kebutuhan TK di tempat yang lebih tinggi. Menyimpan segala peralatan dan kebutuhan dilakukan untuk mengantisipasi kerusakan yang diakibatkan dari bencana banjir.

Hal yang dilakukan oleh partisipan merupakan suatu bentuk antisipasi bencana banjir yang dapat dilakukan sebagai guru. Adapun upaya mobilisasi kesiapsiagaan dilakukan guru kepada orang tua melalui kegiatan parenting dengan memberikan informasi untuk siap siaga menghadapi banjir. Informasi yang disampaikan dalam kesiapsiagaan menghadapi banjir adalah menyiapkan persediaan makanan darurat, menjaga kondisi kesehatan anak ketika banjir terjadi, serta evakuasi ke tempat yang lebih tinggi ketika kedalaman sudah mencapai lutut. Pihak sekolah juga menghimbau agar selalu berhati-hati dengan keberadaan listrik dan jangan melakukan evakuasi pada malam hari karena memiliki risiko yang lebih besar.

Pihak sekolah menginformasikan bahwa orang tua harus selalu mempersiapkan makanan untuk berjaga-jaga. Salah seorang partisipan, M mengatakan "...telur, susu, mi, yang gitu harus selalu ada, jadi kalo pas pada saat banjir tiba-tiba, kita ga kekurangan makanan". 
Partisipan juga telah menginformasikan dengan menghimbau orang tua untuk menyediakan cadangan pangan yang dilakukan sebagai salah satu upaya dalam mengantisipasi dan menanggulangi bencana banjir. Selain bahan pangan, orang tua juga perlu menyediakan peralatan darurat banjir lainnya (BNPB, 2017). Pihak sekolah telah memiliki sensitivitas terhadap kesiapsiagaan serta antisipasi dan penanggulangan bencana banjir, inisiatif tersebut terlihat dari salah satu partisipan yang mengatakan:

"...Kalau ke anak saya suruhnya siapin kantong. Saya sendiri menyiapkan segala amcam dalam satu kantong. Siapin bajunya senditi. Keperluannya sendiri. Masukan dalam satu kantong. Jadi kali ada evakuasi langsung bawa".

Namun tindakan yang telah dilakukan tersebut berbeda dengan yang disarankan oleh BNPB (2016), yaitu mempersiapkan tas siaga bencana yang berisi keperluan yang dibutuhkan seperti makanan kering seperti biskuit, air minum, kotak kecil berisi obat-obatan penting, lampu senter dan baterai cadangan, lilin dan korek api, kain sarung, satu pasang pakaian dan jas hujan, surat berharga, fotokopi tanda pengenal yang dimasukkan kantong plastik, serta nomor-nomor telepon penting. Perbedaan pada persiapan tas siaga disebabkan oleh kurangnya pemahaman yang utuh terhadap bagaimana cara yang seharusnya dalam mengantisipasi bencana banjir.

Sekolah menadi salah satu agensi sosialisasi penting bagi anak-anak di samping keluarga, berbagai program perawatan psikososial menunjukkan keterlibatan guru dalam memberikan perawatan psikososial untuk anak-anak selama bencana . Namun tidak hanya guru, partisipan juga melihat bahwa semua antisipasi dan penanggulangan bencana banjir sebenarnya adalah kesadaran bersama, bukan dari pihak sekolah saja, tetapi juga memerlukan kerja sama dengan masyarakat, dan pemerintah. Namun, hasil wawancara menunjukkan bahwa ketika bencana banjir terjadi tidak banyak yang bisa dilakukan oleh warga, hal tersbut tergambarkan dalam pernyataan "...namanya banjir bencana, kita udah ga bisa apa apa lagi ya". Namun guru yang juga sebagai bagian dari masyarakat juga ikut membantu orang tua dan masyarakat dengan menginformasikan untuk siap siaga menghadapi banjir ketika kondisi curah hujan tinggi. Hal tersebut menurut partisipan perlu dilakukan karena ketika banjir terjadi daerah tempat tinggal partisipan biasanya terisolir dan yang paling terakhir surut, sehingga perlu kesiapsiagaan dan antisipasi untuk bencana banjir.

Informasi untuk menjaga kesehatan anak sebelum dan ketika menghadapi banjir juga sudah tepat, hal tersebut sesuai dengan upaya kesiapsiagaan banjir yang hakikatnya dapat membawa penyakit akibat air dan sampah yang terbawa ketika banjir sehingga dapat menimbulkanpenyakir seperti diare, muntaber, disentri, tifus, kolera, demam berdarah, penyakit kulit dan infeksi saluran pernafasan (Pusat Krisis Kesehatan Kemenkes, 2016). Sayangnya, informasi yang diberikan pihak sekolah pada orang tua tidak sampai pada tahapan upaya yang harus dilakukan untuk mencegah penyakit ketika banjir berlangsung. Pusat Krisis Kesehatan Kemenkes (2016) menyebutkan bahwa hal-hal yang perlu dilakukan untuk menghindari terjangkit ketika banjir berlangsung diantaranya: a) melakukan kegiatan cuci tangan teratur sebelum dan sesudah makan untuk menghindari pencemaran bakteri, b) menghindari konsumsi makanan yang tercemar banjir, c) mengkonsumsi air minum yang telah direbus hingga mendidih, d) menggunakan sarung tangan dan alas kaki ketika membersihkan rumah yang terkena dampak banjir, e) membersihkan lumpur yang terbawa banjir dengan menggunakan cairan pembersih lantai yang mengandung pembunuh bakteri, f) membuang sampah pada tempatnya, dan g) menggunakan pakaian kering untuk menghindari penyakit kulit.

Adapun informasi terkait proses evakuasi banjir yang dinyatakan oleh partisipan yaitu untuk menjangkau tempat yang lebih tinggi ketika air sudah mencapai satu lutut dianggap kurang tepat, karena berdasarkan saran dari BNPB (2017) adalah secepat mungkin 
menuju tempat yang tinggi sejak pertama banjir terjadi yaitu ketika melihat air datang dan jauhi secepat mungkin daerah banjir. Selain itu, jika air telanjur meninggi disarankan untuk tidak keluar dari rumah dan sebisa mungkin meminta pertolongan.Antisipasi dan penanggulangan pada dasarnya perlu dibicarakan lebih lanjut dengan berbagai pihak. Proses harus didorong dengn mengakomodasi pandangan masyarakat dan memperhatikan kemampuan komunikasi dan pesan risiko untuk masyarakat (Abunyewah, Gajendran, \& Maund, 2018). Keinginan dari seseorang yang berprilaku siap siaga bencana perlu dipertimbangkan untuk memiliki kesempatan, keterampilan, dan sarana dalam kehidupannya (Najafi, Ardalan, Akbarisari, Noorbala, \& Elmi, 2017).

\section{Mitigasi Bencana Banjir dalam Program Sekolah}

Partisipan mengungkapkan bahwa pengenalan banjir pada anak dilakukan dalam pembelajaran saat tema alam semesta, sub tema bencana alam. Hal tersebut sesuai dengan pernyataan partisipan L "...misalkan sekarang temanya bencana, kita ambil bencana banjir, terus yang kita jadi sumbernya misalkan kita ambil dari buku paket". Partisipan juga menambahkan bahwa pengenalan bencana banjir dapat dilakukan melalui bercerita tentang pengalaman banjir yang pernah dialami dan tanya jawab terkait apa yang boleh dan tidak boleh dilakukan ketika banjir terjadi. Seperti yang diungkapkan oleh partisipan L:

“.....anak-anak kalau misalkan kita banjir, diusahakan, jangan turun ke air. Jadi kalau nanti turun ke air, kepeleset gimana? Kalau jatuh gimana?.... paling gitu aja, menerapkan kepada anak, diusahakan apabila dalam keadaan banjir, kita mendekat ke orang tua, jangan lepas dari orang tua, jangan berani-berani sendiri main di air..."

Partisipan lainnya mengungkapkan bahwa pengenalan bencana banjir bisa diberikan pada anak namun materinya tidak terlalu dalam. Ketika ditanyakan alasan kedalaman materi tersebut partisipan menjawab sebagai berikut:

“........karena anak kecil itu sifatnya pingin tau ya bu ya, pingin taunya itu besar banget, takutnya coba-coba. Takutnya kadang-kadang dia coba-coba. Jadi harus begitu hati-hati ketika tadi kan ngasih perkenalan ke anak, nah pengenalan bencana banjir teh apa....."

Pendapat partisipan tersebut berbeda dengan yang diungkapkan oleh BNPB (2016) bahwa mitigasi bencana hendaknya diberikan pada setiap warga, termasuk anak, bukan hanya mengenalkan apa itu bencana banjir namu juga sudah lebih luas terkait dengan apa yang harus dilakukan ketika bencana banjir terjadi. Pemberian pengetahuan terkait hal tersebut diharapkan dapat mengurangi faktor risiko atau dampak dari bencana banjir itu sendiri. Informasi lain yang diperoleh dari partisipan yaitu tidak terdapatnya nomor darurat bencana di lembaga/sekolah. Hal tersebut juga menjadi gambaran bahwa masih belum maksimalnya tahapan mitigasi bencana khususnya di lembaga PAUD.

Selain itu, perihal jalur evakuasi untuk bencana alam, partisipan L menyatakan bahwa tidak ada jalur evakuasi yang khusus, jadi tetap menggunakan jalan yang biasa dilalui. Partisipan juga menambahkan bahwa jika terjadi banjir biasanya anak-anak disarankan untuk ke mesjid yang terdekat karena posisinya yang lebih tinggi dari rumah warga. Informasi dari partisipan tersebut menggambarkan bahwa belum terdapat jalur evakusi yang jelas dan dapat dikenalkan pada anak ketika banjir terjadi, informasi pada anak baru sebatas bahwa ketika banjir terjadi harus ke tempat yang tinggi. Hal tersebut belum sesuai dengan mitigasi bencana karena mengingat bahwa jalur evakuasi adalah jalur yang diperuntukkan khusus menghubungkan semua area ke area yang aman sebagai titik kumpul dalam keadaan darurat. Jalur Evakuasi menjadi sangat penting dan mutlak untuk diletakkan sebagai penunjuk arah ketika bencana terjadi (BNPB, 2017). 
Adapun antisipasi yang akan dilakukan oleh guru jika terjadi banjir pada saat pembelajaran di sekolah adalah dengan melakukan evakuasi ke tempat yang lebih tinggi baik itu rumah warga atau mesjid dan sebisa mungkin orang dewasa tidak boleh panik sehingga tetap bisa menjaga kondisi anak dengan baik. Upaya preventif yang dikenalkan oleh guru dilakukan secara terpadu untuk menjawab tantangan pengurangan risiko bencana (Raikes, Smith, Jacobson, \& Baldwin, 2019) pada anak. Dengan pembiasaan membuang sampah pada tempatnya, dan membuat bank sampah, khusunya bagi sampah yang memiliki nilai finansial seperti plastik. Pembiasaan membuang sampah ini diharapkan dapat melekat dalam diri anak sehingga perilaku baik tersebut akan terus dilakukan hingga dewasa, sehingga mampu meminimalisir faktor penyebab banjir.

Berdasarkan seluruh uraian di atas, temuan dalam penelitian ini dapat diringkas dalam gambar sebagai berikut:

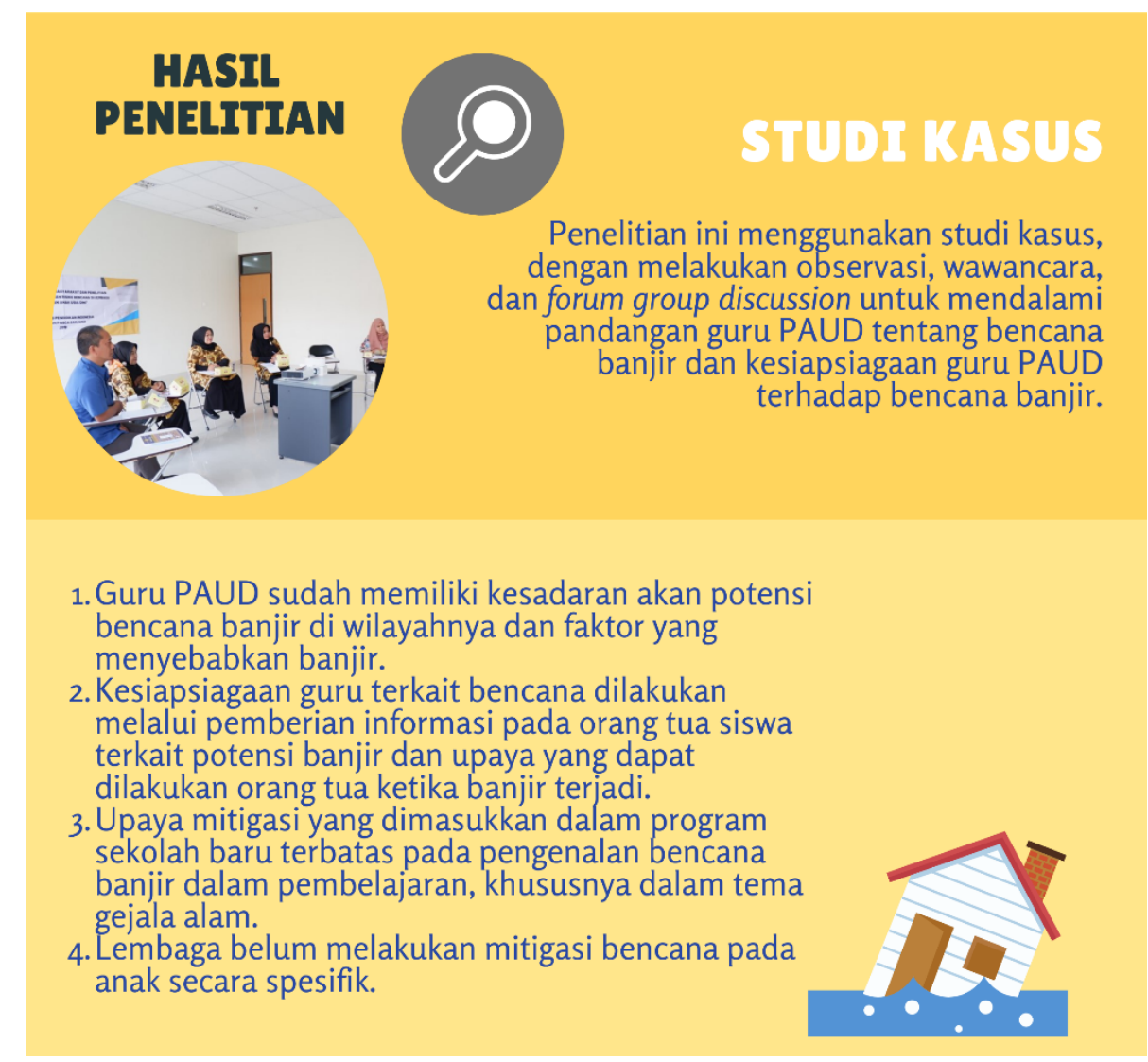

Gambar 4. Ringkasan Data Temuan Penelitian

\section{SIMPULAN}

Guru PAUD sudah memiliki pemahaman dan kesadaran terkait potensi serta dampak dari bencana banjir. Kesiapsiagaan guru dalam menghadapi bencana tercermin dalam pemberian informasi pada orang tua terkait dengan upaya-upaya yang dapat dilakukan selama banjir terjadi. Namun upaya pemberian informasi selama banjir terjadi belum dapat mencapai anak. Anak belum dapat dipercaya untuk menerima informasi mengenai hal-hal apa saja yang perlu dilakukan pada saat bencana banjir. Pembiasaan membuang sampah pada tempatnya sebagai salah satu solusi bagi anak dan orang tua untuk mencegah terjadinya banjir. Adapun implementasi kesiapsiagaan dalam program sekolah belum secara detail, baru pada tahap pengenalan bencana banjir pada anak dalam tema alam semesta yang diberikan dalam kegiatan bercerita dan bercakapa-cakap. Program dalam sekolah belum menyediakan upaya mitigasi bencana banjir seperti jalur evakuasi dan nomor darurat 
bencana. Hal tersebut karena guru belum mendapatkan sosialisasi maupun pelatihan secara langsung bagaimana menerapkan segala proses mitigasi bencana pada anak.

\section{UCAPAN TERIMAKASIH}

Terima kasih kepada Pascasarjana UPI yang telah mendanai penelitian ini dan juga kepada para partisipan yang berkenan terlibat dalam proses penelitian identifikasi kesiapsiagaan guru sebagai upaya penanggulangan risiko banjir di Bandung.

\section{DAFTAR PUSTAKA}

Abunyewah, M., Gajendran, T., \& Maund, K. (2018). Conceptual Framework for Motivating Actions towards Disaster Preparedness Through Risk Communication. Procedia Engineering, 212(2017), 246-253. https:// doi.org/10.1016/j.proeng.2018.01.032

Amri, A., Bird, D. K., Ronan, K., Haynes, K., \& Towers, B. (2017). Disaster risk reduction education in Indonesia: challenges and recommendations for scaling up. Natural Hazards and Earth System Sciences, 17(4), 595-612. https://doi.org/10.5194/nhess-17595-2017

BNPB. (2016). Pendidikan dan Pelatihan Penanggulangan Bencana. Jakarta: BNPB.

BNPB. (2017). Pedoman Latihan Kesiapsiagaan Bencana. Membangun Kesadaran, Kewaspadaan dan Kesiapsiagaan dalam Menghadapi Bencana. Jakarta: BNPB.

Coppola, D. P. (2011). Introduction to International Disaster Management. In Introduction to International Disaster Management. https:/ / doi.org/10.1016/C2009-0-64027-7

Hadi. (2007). Kesiapsiagaan Bencana Berbasis Masyarakat dan Pendekatan. Jakarta: Divisi Penanggulangan Bencana, Palang Merah Indonesia Pusat.

Irzalinda, V., \& Sofia, A. (2019). Pengaruh Koping Strategi terhadap Resilience Keluarga Rawan Bencana. Jurnal Obsesi: Jurnal Pendidikan Anak Usia Dini, 4(1), 201. https://doi.org/10.31004/obsesi.v4i1.312

Ispranoto, 2018. Hujan Angin, Cicaheum Bandung Banjir Cileuncang Setengah Ban. [online]: https://news.detik.com/berita-jawa-barat/d-3924459/hujan-angin-cicaheumbandung-banjir-cileuncang-setengah-ban.

Kodoatie, \& Syarief. (2002). Banjir: Beberapa Penyebab dan Metode Pengendaliannya, dalam Perspektif Lingkungan. Yogyakarta: Pustaka Pelajar.

Kurniasih, N. (2016). The Model of Disaster Information Dissemination Based on Volunteer Communities: A Case Study of Volunteer Communities in Bandung Regency, West Java, Indonesia. Proceedings of the International Conference on Library and Information Science, (4), 285-313. Taipei: IBAC Taipe Taiwan. https://doi.org/10.31227/osf.io/687dv.

Kurniasih, N., \& Sukaesih. (2017). Public Health Information Behavior at Flood-Prone Area In Bandung Regency: A Case Study in Baleendah Village, Andir Village, Bojongsoang Village and Dayeuh Kolot Village. Journal of Chemical Information and Modeling, 3(1), 19. https:// doi.org/10.1017/CBO9781107415324.004

Kusuma, M. S. B., Kuntoro, A. A., \& Silasari, R. (2011). Preparedness Effort toward Climate Change Adaptation in Upper Citarum River Basin, West Java, Indonesia. Society for Social Management Systems Internet J Ournal, 7(1). Retrieved from https://core.ac.uk/download/pdf/59110673.pdf

Mutch, C. (2014). The role of schools in disaster preparedness, response and recovery: what can we learn from the literature? Pastoral Care in Education, 32(1), 5-22. https://doi.org/10.1080/02643944.2014.880123

Mutch, C. (2015). The role of schools in disaster settings: Learning from the 2010-2011 New Zealand earthquakes. International Journal of Educational Development, 41, 283-291. https://doi.org/10.1016/j.ijedudev.2014.06.008

Najafi, M., Ardalan, A., Akbarisari, A., Noorbala, A. A., \& Elmi, H. (2017). The Theory of Planned Behavior and Disaster Preparedness. PLoS Currents, 9, 1-16. 
https:/ / doi.org/10.1371/currents.dis.4da18e0f1479bf6c0a94b29e0dbf4a72

Pfefferbaum, B., Pfefferbaum, R. L., \& Van Horn, R. L. (2018). Involving children in disaster risk reduction: the importance of participation. European Journal of Psychotraumatology, 9, 1-6. https://doi.org/10.1080/20008198.2018.1425577

Prihanggo, M., Darmawan, S., \& Wikantika, K. (2014). Identification of water inundation using quickbird and also palsar sattelite image study case: Dayeuhkolot subdistrict, Bandung district. Jurnal Ilmiah Geomatika, 20(2), 129-134.

Proulx, K., \& Aboud, F. (2019). Disaster risk reduction in early childhood education: Effects on preschool quality and child outcomes. International Journal of Educational Development, 66(January), 1-7. https://doi.org/10.1016/j.ijedudev.2019.01.007

Purwani, A., Fridani, L., \& Fahrurrozi, F. (2019). Pengembangan Media Grafis untuk Meningkatkan Siaga Bencana Banjir. Jurnal Obsesi : Jurnal Pendidikan Anak Usia Dini, 3(1), 55. https://doi.org/10.31004/obsesi.v3i1.142

Pusat Krisis Kesehatan Kemenkes. (2016). Video Animasi Pesan Kesiapsiagaan Banjir. Retrieved from https://www.youtube.com/watch?v=EV1DkiCgkn0.

Raikes, J., Smith, T. F., Jacobson, C., \& Baldwin, C. (2019). Pre-disaster planning and preparedness for floods and droughts: A systematic review. International Journal of Disaster Risk Reduction, 38, 1-9. https:// doi.org/10.1016/j.ijdrr.2019.101207

Rosyidie, A. (2013a). Banjir: Fakta dan Dampaknya, Serta Pengaruh dari Perubahan Guna Lahan. Journal of Regional and City Planning, 24(3), 241-249.

Rosyidie, A. (2013b). No Title. Jurnal Perencanaan Wilayah Dan Kota, 24(3), 241-249. https:// doi.org/http://journals.itb.ac.id/index.php/jpwk/article/viewFile/4110/2 196

UNISDR. (2010). Synthesis Report on Ten ASEAN Countries Disaster Risks Assessment. ASEAN Disaster Risk Management Initiative.

Van Ackere, S. (2019). Flood Impact Assessment Tool (FLIAT) An Object-Relational GIS Tool for Flood Impact Assessment in Flanders, Belgium Samuel. https:// doi.org/10.3390/w11040711

Yin, R. K. (2014). Case study research design and methods (5th ed). In Sage. Thousand Oaks: Sage. 